Sylwia Nowak-BAJCAR

Uniwersytet Jagielloński

\title{
Opisać nieprzedstawione. Malarstwo holenderskie w antyobrazach Miodraga Pavlovicia
}

Już pierwszy tomik poezji Miodraga Pavlovicia (1928-2014) 87 pesama (87 wierszy) z 1952 roku zawierał elementy autotematyczne, poświadczające wysoki stopień samoświadomości artystycznej, która przejawiała się w podejmowaniu przez tego autora problemów twórczości własnej, tradycji narodowej i jej relacji $\mathrm{z}$ tradycją europejską. Dokonania literackie serbskiego poety oraz jego działalność krytycznoliteracka wyrastały zarówno ze sprzeciwu wobec ideologicznego klimatu lat pięćdziesiątych xx wieku (Palavestra 2008: 585), jak i z prób jego przełamywania w duchu tradycji neoromantycznej, której przejawem była jesieninowska subiektywistyczna, nastrojowa i melancholijna liryka wewnętrznego przeżycia, będąca wyrazem dystansu wobec optymizmu i entuzjazmu stereotypowego patosu socrealistycznej „roboty” poetyckiej (Kornhauser 1980: 23). Zaznaczająca się od pierwszych utworów Pavlovicia samoświadomość generowała potrzebę namysłu nad sensem nowoczesności i refleksję nad znaczeniem tego terminu w odniesieniu do własnej kultury narodowej, u źródeł której tkwiły tradycje zarówno bizantyńskiego Wschodu, jak i kultury Zachodu. Z prób przezwyciężenia tej (i innych) dychotomii wyrasta nie tylko poetycki, ale także eseistyczny dorobek Pavlovicia, a także jego działalność redakcyjna (jej zwieńczeniem jest niemająca sobie równych do chwili obecnej Antologija srpskog pesništva: XII-XX vek (Antologia poezji serbskiej: XII-XX wiek) z 1964 roku), które, jak dotąd, nie doczekały się całościowego omówienia. Wydane 
dotychczas tomy zbiorowe oraz publikacje (Despić 2008; Đorđević 1984, 1997; Kocić 1996; Kordić 1976; Popović 1985) mają charakter cząstkowy, nie są więc w stanie zaoferować pełnego oglądu dokonań Pavlovicia oraz wskazać ich znaczenia dla kultury serbskiej. Przyczynia się do tego z jednej strony liczba i różnorodność jego dzieł (twórczość poetycka obejmuje przeszło 30 tomików wierszy, zaś eseistyczna - około 20 zbiorów), z drugiej strony erudycyjny tryb prowadzonej przez Pavlovicia refleksji - dystans i ironia, poruszanie się po obszarach wielu dyscyplin (filozofia, kultura, etnologia, historia) sprawiają, że jego twórczość nie poddaje się łatwo próbom systemowego opisu i uogólnieniom.

Pomimo tego brak całościowej monografii poświęconej twórcy zaskakuje tym bardziej, że jego status i ranga dokonań zostały potwierdzone przez badaczy w Serbii przyznaniem mu miana „eliotowskiej figury” literatury serbskiej. U źródeł porównań tego poety do angloamerykańskiego twórcy tkwią zarówno wspomniany już wysoki stopień poetologicznej samoświadomości (Brajović 2010: 112), rola, jaką przyznaje on dialogowi nowoczesności z tradycją (Delić 2010: 48), potencjał rewindykacyjny jego działań, jak i inspirowany koncepcjami Eliota „program” wycofania osobowości twórczej na rzecz koncepcji podmiotu jako medium przeszłości i teraźniejszości oraz różnorodnych kultur, który - do pewnego stopnia - połączyć możemy z ideowymi koncepcjami spod znaku New Critisism.

Ujmując problem z szerszej i odleglejszej perspektywy, aktywność Pavlovicia wpisuje się w działalność serbskich intelektualistów, którzy w latach sześćdziesiątych i siedemdziesiątych podejmowali próby zrewidowania i przewartościowania własnej tradycji kulturowej (Dąbrowska-Partyka 2003a: 206-207, 2003b: 274, 2004: 140-141) poprzez umieszczanie jej w szerokim kontekście europejskim, pokazywanie źródeł i miejsc wspólnych oraz odchodzenie od wskazywania elementów świadczących o odrębności traktowanej w kategoriach zjawiska wyjątkowego. W tym celu Pavlović posługiwał się pojęciem specyficznie rozumianego „antyobrazu”, które wykorzystywał nie tylko w refleksji poświęconej własnej sztuce poetyckiej, ale także w rozważaniach nad istotą nowoczesności.

W pochodzącym z tomu Dnevnik pene. Eseji (Dziennik piany. Eseje, 1972) tekście zatytułowanym Modernost i pesništvo (Nowoczesność i poezja) stwierdzał:

Antyobraz podważa aktualną mitologię danego społeczeństwa, kwestionuje konformistyczną psychologię życia codziennego, zrutynizowane formy odczuwania, reakcje, a nawet niezmienne ideały. [...] Antyobraz poddaje krytyce psychologiczną, polityczną, aksjologiczną fasadę społeczeństwa, [...] sztukę cieszącą się społeczną akceptacją. [...] Antyobraz 
nie ma charakteru polemicznego ani politycznego, ponieważ jest usytuowany w głębszych warstwach wyobraźni, wywodzi się z głębszych prawidłowości społecznej psychologii. Nowoczesnego obrazu poetyckiego nie należy utożsamiać z realizmem w sztuce, bez względu na stopień jego krytycyzmu. Realizm zawsze akceptuje zastaną przestrzeń codzienności, nawet jeśli chce ją modyfikować (Pavlović 2018a: 264)ํ․․

Wyostrzona polemiczna samoświadomość jest według serbskiego twórcy nieodłącznym atrybutem poezji. Wskazując autoreferencjalność jako ważny element antyobrazu, który - jak stwierdza - „poddaje krytyce nawet własne środki artystyczne” (Pavlović 2018a: 265), Pavlović odżegnuje się od prób jej socrealistycznego uprzedmiotowienia. Z drugiej strony, pisząc, że „czysta krytyka środków wyrazu nie jest antyobrazem” (Pavlović 2018a: 265), głosi on potrzebę odcięcia się od artystycznych przedsięwzięć prowadzących do wyobcowywania poezji poprzez wyznaczanie jej funkcji autotelicznej.

Sztuka zajmuje poetę w aspekcie uniwersalnym jako dziedzina ludzkiej działalności, w której szuka on odpowiedzi na pytanie o kondycję ludzkości $\mathrm{i}$ istotę człowieczeństwa. Podejmując to zagadnienie, zainicjowane w jego pierwszym tomiku doświadczeniem II wojny światowej, w późniejszych zaś zbiorach próbami zgłębienia przyczyn upadku Bizancjum, poeta próbuje także dotrzeć do źródeł wpisanego w świat ludzki zła i w tym celu zwraca się ku wszystkim przejawom kulturotwórczej działalności człowieka. Namysł nad sztuką wpisuje się zatem w rozważania antropologiczne Pavlovicia, poświęcone tym doświadczeniom ludzkości, które, niezależnie od tego, czy dotyczą Wschodu czy Zachodu, przeszłości czy teraźniejszości, niezmiennie potwierdzają konieczność powrotu do mitu w rozumieniu tego słowa przyjętym przez Hansa Blumenberga: jako źródła poddawanych nieustannej aktualizacji i weryfikacji uniwersalnych prawd o człowieku².

1 Esej ten został przełożony na język polski przez Joannę Salamon (Pavlović 1979: 8-9), jednak ze względu na pewne odstępstwa od oryginału i nieuzasadnione pominięcie przez tłumaczkę jednego zdania, istotnego dla rozważań podjętych w artykule, przywołany fragment oraz kolejne podaję we własnym tłumaczeniu - S.N.B.

2 Pojęcie „antyobrazu” nasuwa skojarzenia z pojęciem Gadamerowskiej „antysztuki” (Gadamer 1993: 47-49), jednak dla twórczości Pavlovicia bardziej adekwatny, jak się wydaje, kontekst filozoficzny stanowią rozpoznania Hansa Blumenberga i jego koncepcja nowoczesności oraz działalności artystycznej człowieka. Z Blumenbergowską ideą całkowitego nowatorstwa sztuki nowoczesnej koresponduje teza Pavlovicia, że „nowoczesność to za każdym razem coś innego" (Pavlović 1981: 202-262), natomiast idea mitów fundamentalnych niemieckiego filozofa, które podlegają ciągłym modyfikacjom 
Ten humanistyczny wymiar poezji Pavlovicia ujawnia się także w zainteresowaniu malarstwem holenderskim, które stało się przedmiotem refleksji poety w trzech zaledwie utworach pochodzących z poświęconego zagadnieniom sztuki tomiku poetyckiego Ulazak u Kremonu (Przybycie do Cremony) z 1989 roku3 . Utwory te są rodzajem ekfraz, których cechą jest, na co wskazują teoretycy, silnie zaznaczająca się autorefleksyjność (Markowski 1999: 13; Dziadek 2004: 40-41), stanowiąca także wyróżnik antyobrazów Pavlovicia. Będą one w niniejszym tekście materiałem egzemplifikującym próby asymilacji przez poetę malarstwa Zachodu jako elementu własnej (bo odwołującej się do wspólnych doświadczeń historycznych całego świata chrześcijańskiego) tradycji kulturowej, ale także materiałem ilustrującym próby odczytania dzieł holenderskich mistrzów przez pryzmat sposobów ujawniania się w nich ludzkiej obecności. Wybór dzieł, w których jako motyw przewodni (czy to na poziomie poetyckiego obrazowania, czy na poziomie tematyki) pojawia się architektura, jest wyraźnym przejawem zainteresowania twórcy tą problematyką. Wszak architektura, co potwierdza jej definicja, ,jest sztuką i umiejętnością, umożliwiającą organizację i kształtowanie elementów przestrzennych, służących zaspokajaniu materialnych i duchowych potrzeb ludzi” (Biegański 1974: 28).

i metamorfozom w procesie ich aktualizowania, czyli nieustannemu mitotwórstwu, które filozof nazywa „pracą nad mitem” (Blumenberg 2009: 15), znajduje swój odpowiednik w stwierdzeniu Pavlovicia: „Powrót motywów mitycznych w literaturze jest przede wszystkim następstwem zmiany poglądów na mitologię, następstwem pewnej nowej świadomości o człowieku, którą zawdzięczamy rozwojowi antropologii i socjologii. Stąd wywodzi się wzrost zainteresowania dawną tematyką mityczną, jednakże zainteresowanie to sprowadza się raczej do burzenia widzenia klasycznego i tworzenia przez imaginację poetycką nowych wyobrażeń, integralnie ludzkich, wynikających z dużej samowiedzy. Podjęcie przez współczesność tematyki mitycznej nie jest tradycjonalizmem, raczej przeobrażeniem duchowym obejmującym nie tylko literaturę: to nowy rozdział w samookreśleniu się człowieka jako jednostki i historycznie uwarunkowanego zbiorowiska" (Pavlović 1979: 29-30).

3 Pomimo dużych możliwości odczytania w kluczu intersemiotycznym utworów zebranych w przywołanym tomie, potencjał ten dotąd nie został wykorzystany przez badaczy w Serbii poza jednym artykułem, którego autorka jako przykład zjawiska ekfrazy wskazuje jedynie dwa wiersze: omawiany w niniejszym artykule utwór Emanuel de Vite: Devojka za virginalom oraz Giorgione: La tempesta (Stojanović-Pantović 2010: 433-448). Z kolei Đorđe Despić w swojej książce Poreklo pesme (Pochodzenie wiersza) bada utwory z tomiku Ulazak u Kremonu pod kątem intertekstualności (Despić 2008: 113-123), ale odczytanie związków pomiędzy różnymi tekstami kultury wyłącznie przez pryzmat odwołań do mitów antycznych i biblijnych jako, zdaniem badacza, kluczowych w twórczości Pavlovicia bardzo zawęża możliwości interpretacyjne jego utworów. 
Problematykę tę podejmuje Pavlović w utworze Sanredam: Unutrašnjost katedrale (Saenredam: wnętrze katedry) (Pavlović 1989: 77), który - jak pozostałe analizowane w niniejszym tekście wiersze Pavlovicia - przywołuję w całości wraz z przekładem własnego autorstwa:

Sanredam: Unutrašnjost katedrale

Slikati zidove gole

ćelavu belinu

svodove koji podupiru

graditeljsku

perspektivu

razmišljati o površinama

bez slike.

Smiren je bes

ikonoborca,

pas ide po pustoši

hramnoj

razvodi crne figure

i šešire.

U posmatrača je prešlo mesto

paradoksa:

Slikati sliku

o neslici

znači li uzdići

ponos

slikoubice?

Ili je to dokaz

da i praznina

hoće da vidi

svoje lice!

Saenredam: Wnętrze katedry

Malować ściany nagie

łysą biel

sklepienia które wspierają

perspektywę 


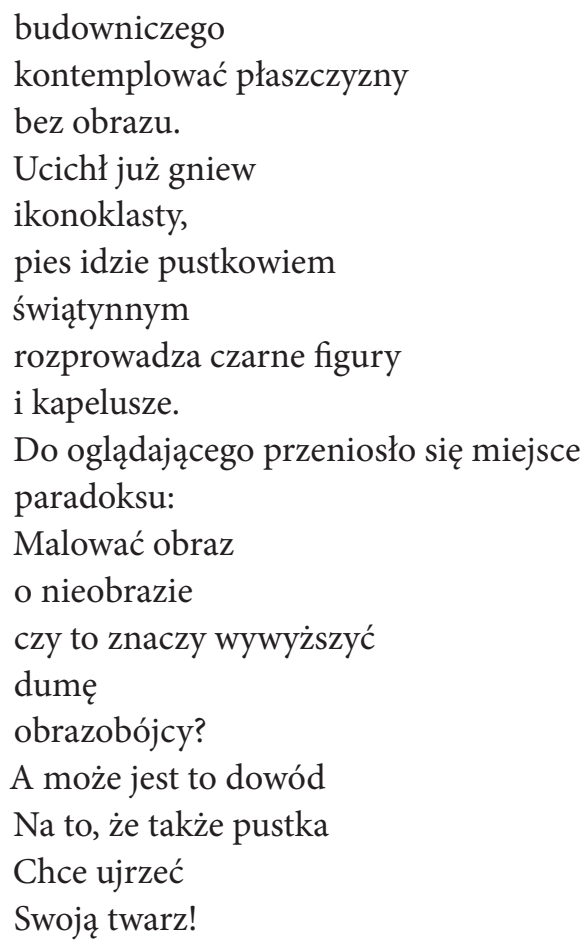

Choć epitety pojawiające się w opisie dzieła malarskiego uznać moglibyśmy za typowy repertuar określeń w wypowiedziach na temat sposobu doświadczania protestanckich świątyń („ogołocone wnętrze”, „nagie ściany”, „łysa biel”) 4 , tematem wiodącym wiersza nie są wrażenia podmiotu obcującego z dziełami wybitnego portrecisty kościołów, lecz namysł nad jego celem i przyświecającymi mu intencjami. Bezosobowa forma równoważników zdań uniemożliwia ujaw-

4 Jako ilustrację tej typowości przywołuję w tym miejscu opis recepcji wnętrz holenderskich świątyń: „To było moje najsilniejsze przeżycie plastyczne Holandii: wnętrze ogołoconej przez obrazoburczą Reformację gotyckiej katedry. Wrażenie niezapomniane. Czternastowieczny gotyk (w Delft, Haarlemie, Utrechcie) sprowadzony do samej architektury. Ani jednego ołtarza, ani jednej rzeźby, ani jednego obrazu. Strzelistość kolumn i jasna biel ścian. Nic nie skupiało uwagi, wszystko ją rozpraszało. Była rozbita pomiędzy jasność i strzelistość. Po raz pierwszy w życiu doznałem piękna nagiej architektury. Patrzyłem jakbym po raz pierwszy oglądał. A przecież niewiele dni przedtem w Bruges i w Antwerpii gotyk katolickich katedr mnie upoił. Ale tamta strzelistość była obciążona bogactwem rzeźb ołtarzy, bogactwem obrazów (olbrzymie Rubensy w Antwerpii), które ciągnęly oczy to w tę, to w tamtą stronę. A tu żadnej dystrakcji, czysty lot" (Bieńkowski 1993: 69). 
nienie się podmiotu lub jego identyfikację, obecne w wersach bezokoliczniki sprawiają zaś, że eliptyczne wypowiedzenie nabiera charakteru refleksyjnego pytania retorycznego. Co znaczy:

\author{
Malować ściany nagie \\ tysą biel \\ sklepienia które wspierają \\ perspektywę \\ budowniczego \\ kontemplować płaszczyzny \\ bez obrazu
}

\title{
- zastanawia się Pavlović.
}

Zdepersonalizowana wypowiedź oddaje „okaleczony” charakter wnętrza pozbawionego przedstawień malarskich oraz przedmiotów kultu, będących znakami odróżniającymi świątynie. Podobnym wybrakowaniem, niepełnością odznacza się tytuł utworu. Brak dookreślenia nazwy kościoła wskazuje na fakt, że utwór Pavlovicia nie jest ekfrazą, opisem konkretnego dzieła malarskiego, lecz hypotypozą, która - jak pisze Adam Dziadek - „odwołuje się do zbioru ogólnokulturowej wiedzy czytelnika, do jego kompetencji” i odsyła go

[...] nie tyle do konkretnego malowidła, ile właśnie do całej klasy płócien o podobnej tematyce. Opis w hypotypozie - w przeciwieństwie do opisu w ekfrazie - nie odnosi się do konkretnego dzieła sztuki, ale raczej pośrednio przywołuje jakiś obraz i narzuca czytelnikowi konieczność ustalenia ścisłych kryteriów pozwalających wskazać w tekście wyznaczniki malarskości bez posługiwania się prostą analogią. Figura ta zdaje się sugerować analogię z jakimś obrazem lub z jakimś charakterystycznym typem obrazowania malarskiego (Dziadek 2004: 82).

Gdyby na podstawie zawartych w utworze wskazówek próbować dookreślić, który z obrazów holenderskiego malarza opisuje poeta, to okazuje się, że o ile na wielu płótnach Saenredama przedstawiających wnętrza kościołów można odnaleźć przywołane w wierszu Pavlovicia czarne figury, kapelusze oraz psa (np. Interior of the Nieuwe Kerk, Haarlem 1653, Szepmüveszeti Muzeum, Budapest; The interior of the Buurkerk at Ultecht, 1644, National Gallery, London; Interior of the Nieuwe Kerk, 1652, Franse Hals Museum, Haarlem), jedynym dziełem prezentującym potwierdzone tytułem wnętrze katedry jest nie obraz malarski, lecz rysunek, na którym wspomniane elementy się nie pojawiają 
(Wnętrze Katedry św. Marcina, Utrecht). Można więc stwierdzić, że w ujęciu Pavlovicia wnętrza malowane przez Saenredama przedstawiają uniwersalną świątynię, sam utwór serbskiego poety stanowi zaś opis idiomu artystycznego holenderskiego malarza oraz refleksję nad sensem przedstawiania przez niego pustych ścian, a więc pewnego braku. Ów brak jest pustką znaczącą, będącą efektem dewastacji - ma zatem swoją przyczynę.

Wiersz tematyzuje sposób malarskiego ujęcia wnętrza świątyni ogołoconej z obrazów, poddaje refleksji powody przedstawienia przez Saenredama pustki, która - zdaniem Pavlovicia - jawi się odbiorcy tego malarstwa jako paradoks. Bieli ścian na portretach malowanych przez Saenredama wnętrz świątyń Pavlović nie łączy z refleksją na temat sztuki czystej, z malarstwem abstrakcyjnym czy tė̇ $\mathrm{z}$ artystycznymi próbami przedstawienia sacrum $\mathrm{w}$ duchu filozofii negatywnej - jako nicości ${ }^{5}$, lecz uznaje ją za „nieobraz”, czyli brak, będący znakiem wydarzeń z roku 1566, kiedy to w Niderlandach doszło do usuwania z kościołów przedmiotów religijnego kultu, obrazów religijnych oraz malowanych ołtarzy. Stwierdza:

\author{
Ucichł gniew \\ ikonoklastów, \\ pies idzie pustkowiem \\ świątynnym
}

5 Jan Białostocki, wywodząc przeżycie przestrzeni u Saenredama z doświadczenia Sacrum, stwierdza: „Ten nieustannie powtarzany, choć oparty na rozmaitych rzeczywistych budowlach i ukazujący się w zróżnicowanych formach, jednak jakby wciąż jeden kościół staje się dla obserwatora wielką metaforą, symbolem wszechświata. Ta kosmiczna świątynia, którą przenika ożywcze światło, symbol boskiego ducha, zawiera w sobie świat ludzki. Życie toczy się w nim tak jak w świecie realnym. Ludzie zachowują się tak jak zawsze. Nie modlą się; choć przebywają w kościele, jednak jakby nie myśleli o Bogu, ku którego czci zostały przecież wzniesione te ogromne budowle. Załatwiają swoje drobne sprawy, kierują się swymi namiętnościami, ulegają swym szaleństwom. Przypadkowości i chaotyczności, jakie znamionują świat ludzi, przeciwstawia się ład i doskonałość architektury. Światło delikatnie modeluje formy, które współbrzmią w doskonałej zgodności, ujawniając jakby rządzącą nimi divina proportio. To harmonijne współbrzmienie znajduje symboliczny wyraz w organach - obrazie muzycznej harmonii - które są nieraz jedynym elementem wyposażenia architektury Saenredama. $\mathrm{Z}$ takiej harmonii form, $\mathrm{z}$ takiego nastroju powstaje specyficzna poezja tych obrazów, wiążąca w cudowny sposób to, co świeckie, z tym, co święte, i wyrażająca sacrum przez doskonałość abstrakcyjnej, dzięki światłu odmaterializowanej formy. Wracamy jakby do epoki gotyku, do tych koncepcji, które przyczyniły się niegdyś do powstania architektury, stanowiącej teraz przedmiot malarskiego naśladowania" (Białostocki 1989: 42-43). 
rozprowadza czarne figury

i kapelusze.

Pavlović postrzega zatem twórczość Saenredama jako wyraz problemów religijnych, których początki - dodajmy - sięgają czasów Bizancjum i stanowią, przyjmujące zróżnicowane formy, doświadczenie kulturowe całego świata chrześcijańskiego. Zainteresowanie tą tematyką znajduje potwierdzenie w eseju Pesnička imaginacija kao neposredno iskustvo (Wyobraźnia poetycka jako doświadczenie bezpośrednie), będącym dopełnieniem zawartej w utworze refleksji. Wskazując na różnice w sposobie rozumienia ikony w rzymskim i bizantyńskim kręgu kulturowym, Pavlović stwierdza (fragment przywołuję we własnym tłumaczeniu - S.N.B. ${ }^{6}$ ):

$\mathrm{Na}$ Wschodzie uważano ją za jedną z form lub analogię wcielenia. Była skromnym, lecz cennym przykładem uświęcenia, zstąpienia ducha w materię. Na Zachodzie w czasach sporów o ikony wydawała się przestrogą w łańcuchu religijnych wspomnień. Mniej sakralna, ikona zachodnia była bardziej plastyczna, bardziej podatna na przemiany i wpływy historyczne. Zobowiązywała w mniejszym stopniu: stawała się sztuką. Jeśli spojrzymy na historię ikony, nasz wzrok nieuchronnie zatrzyma się na okresach napływu fal ikonoklazmu, kiedy głos obrazoburcy nabiera mocy, a w pochody wojenne ruszają przeciwnicy przeobrażenia słowa $\mathrm{w}$ ciało, przeciwnicy ciała, które staje się obrazem, nieuznający żadnego pomostu, łączącego to, co niebiańskie z ziemskim. [...] Można by stwierdzić, że czciciele ikon na Zachodzie i Wschodzie różnili się, a ikonoklaści wszędzie byli tacy sami. Nie sądzę jednak, by to była prawda. Im większą czcią otacza się ikonę, tym większy jest rozmiar zniszczeń, jakich dokonuje obrazoburca. Wiedzieli o tym ikonoklaści ze Wschodu, dewastując gruntowniej, bardziej żarliwie, namiętnie, nieodwracalnie. Na Zachodzie skala spustoszeń była mniejsza, tamtejszymi ikonoklastami nie powodowała taka pasja. Na Wschodzie byli oni demonami cierpiącymi na bezsenność. [...] Tylko oni pracowali dzień i noc, zawsze czujni (Pavlović 2018b: 265-266).

Ośrodkiem zainteresowania poety są przyczyny ogołocenia świątynnych ścian, działania, które postrzega on jako ingerencję w wolność twórczą. Wnętrze świątyni Saenredama staje się w ujęciu serbskiego poety przestrzenią oczysz-

6 Por. tłumaczenie Salamon (Pavlović 1979: 12-13). 
czoną z elementu ludzkiego, zaś ikonoklazm (którego skutkiem był przecież rozwój malarstwa świeckiego) jest wartościowany negatywnie, co znajduje wyraz w prowokacyjnym zapytaniu, czy intencją przyświecającą malarzowi była pochwała - jak stwierdza poeta - „obrazobójcy”. Utwór staje się zatem dobitnym komentarzem protestanckiego ikonoklazmu, ocenionego przez Pavlovicia jako dehumanizacja sztuki. Jej przejawem jest także fakt nazwania postaci ludzkich widniejących na obrazach Saenredama mianem figur, w których rozpoznajemy ludzi za sprawą ich wyposażenia przez poetę w czarne kapelusze. Omawiając sposób odczytania wizerunków człowieka na płótnach Saenredama przez Zbigniewa Herberta, który, nota bene, w swoich rozważaniach pomijał kwestie protestanckiego ikonoklazmu (Kluba 2016: 122), Magdalena Śniedziewska stwierdza:

Herbert [...] kpi sobie z postawionej przez Barthes'a tezy, jakoby Saenredam był „niemal malarzem absurdu” i „niebytu”, tezy, nomen omen, absurdalnej. Sportretowana architektura ma - zdaniem Herberta znaczenie symboliczne, jest odbiciem ładu świata, w którym człowiek odnajduje swoje miejsce. Poeta podkreśla, że Saenredamowi udaje się uciec z pułapki nicości dzięki „ludzkim” punktom odniesienia - są to najpierw tablice kommemoratywne, upamiętniające obecność, i wreszcie „małe grupki osób”. A więc pojawia się człowiek, który z jednej strony pozwala widzowi uzmysłowić skalę architektonicznej konstrukcji, z drugiej - co sugeruje uniwersalizujące porównanie ludzi do „małych czarnych sekund na kamiennym zegarze architektury” - jest „miarą wszystkich rzeczy" (Śniedziewska 2014: 429-430)․

Przywołana przez badaczkę teza Rolanda Barthes'a pochodząca z eseju Le Monde-Object (Barthes 1964: 19-28), w którym francuski filozof przestrzeń przedstawionych przez Saenredama wnętrz nazywa „nieodwołalnie bezludną”, ich autora określa zaś mianem malarza absurdu i niebytu oraz negacji podmiotu, jest do pewnego stopnia bliska odczytaniu Pavlovicia. Do pewnego stopnia, ponieważ dla Barthes’a wymiar społeczny ikonoklazmu, wydobywany dobitnie

7 Śniedziewska zwraca uwagę na dwa elementy, które w rozważaniach o „bezludności” dzieł Saenredama nabierają wymiaru symbolicznego. Na kwestię po pierwsze - autorstwa pojawiających się na obrazach holenderskiego malarza postaci ludzkich, które przypisuje się innemu twórcy oraz - po drugie - instrumentalnej funkcji tych wizerunków, będących jedynie „punktem odniesienia” dla architektonicznego portretu (Śniedziewska 2014: 430-431). 
przez Pavlovicia, był problemem drugorzędnym. Natomiast wydaje się, że zainteresowania Barthes'a Saenredamem nie można sprowadzić do rangi naukowego ekskursu francuskiego filozofa oczarowanego niepowtarzalnością artystycznego idiomu malarza, lecz wywieść je należy z zainteresowania Barthes’a sztuką awangardową. Twórczość holenderskiego twórcy stanowiła dla myśliciela rodzaj inauguracji pewnej typowej dla awangardy strategii artystycznej, strategii ciszy (Caygill 2002: 38-48), która jest także przedmiotem zainteresowania Pavlovicia.

Podobnie jak Barthes, który stwierdzał: „Saenredam jest paradoksem: za pomocą antytezy artykułuje naturę klasycznego malarstwa holenderskiego, które usunęło religię, ustanawiając w jej miejscu człowieka i jego imperium rzeczy" (Barthes 1964: 19), bezludność przestrzeni portretowanej przez Saenredama Pavlović postrzega jako zaprzeczenie istoty malarstwa holenderskiego, jego antyobraz. $\mathrm{W}$ wieńczącym utwór pytaniu retorycznym:

A może jest to dowód

$\mathrm{Na}$ to, że także pustka

Chce zobaczyć

Swoją twarz!

wyrażony jest ten aspekt antyobrazu Pavlovicia, który łączy się z problematyką reprezentacji, wyrażania i uobecniania. Zauważmy, że - paradoksalnie - pustka będąca pozostałością po usuniętych portretach zostaje w wierszu spersonalizowana, obdarzona twarzą, a więc uczłowieczona; co więcej, pragnie ona ujrzeć swoje oblicze, które jest w istocie obliczem ludzkości. Brak widniejący na obrazie Saenredama domaga się ewokacji, zapełnienia, co serbski poeta czyni: chęć zobaczenia własnego wizerunku przez pustkę możemy rozpatrywać jako potrzebę zobrazowania jej przyczyn, czyli działań podejmowanych w imię ikonoklazmu, oraz jako poetycką próbę przywrócenia obrazów (sacrum przedstawionego za pomocą postaci ludzkich, zantropomorfizowanego) na swoje miejsce, ale także jako metaforę poświadczającą potencjał autoreferencjalny tego utworu. Zauważmy, że we wspomnianym wcześniej eseju Wyobraźnia poetycka jako doświadczenie bezpośrednie Pavlović przywołuje określenia wiersza jako „werbalnej ikony” czy „werbalnego obrazu” (Pavlović 2018b: 265), a następnie doświadczenie ikonoklazmu odnosi do poezji: „Przed nimi [obrazoburcami S.N.B.] - pisze - musi stanąć bezbronny poeta. Zostanie oskarżony o kłamstwo i napadnięty przez hordę ikonoklastów, która nocą plądruje domy w poszukiwaniu obrazów lśniących złotem"\$ (Pavlović 2018b: 266). Obrazowanie pustki,

8 Tłumaczenie moje - S.N.B. Por. przekład Joanny Salamon (Pavlović 1979: 11). 
która chce się przyjrzeć sobie, mówi o potrzebie autorefleksji, jest obnażeniem metody ewokacji prawdy przez redukcję i negację, wpisującej się w autokrytyczny potencjał antyobrazu będącego wyrazem wymierzonej w dogmatyzm estetyki oporu Pavlovicia oraz przekonania, że sztuka stanowi narzędzie umożliwiające człowiekowi samopoznanie.

Kwestie uobecniania podejmuje serbski poeta także w utworze Holandska mrtva priroda (Holenderska martwa natura) (Pavlović 1989: 79), wpisującym się w problematykę konsekwencji protestanckiej reformacji i jej wpływu na rozwój świeckiego malarstwa holenderskiego9:

\section{Holandska mrtva priroda}

Hrana bez onog koji jede. Komad hleba

i riba - uvek su večera „tajna”; školjke

i stakla sa nekog nepoznatog oltara.

Jutro sija na sečivu i na dršci noža

od ahata; crveni ćilim je nabor

mnogostruko usirene krvi. Plod se

nevidljivom rukom ljušti, zatim,

svoju glavu seče i na tanjir stavlja.

Čaše su dignute kao jedra što brode

na svetlost. Sa kineskog čanka

svešteni starac gleda svoj doručak

nasleđen od žrtvenog obreda i dara.

I providna lala se diže u vis

kao žito vaskrslo s njive.

\section{Previše možda}

o poreklu predmetne arhitekture grupne

koju mrtvom prirodom zovu.

U njoj ima više filosofije stvari

no značenja i emblema. Tu, između

skupocenih vaza, narandži,

grožđa i raspojasane divljine sa kopna

9 Podobną tematykę przemian gatunkowych i nobilitacji tematów „prozaicznych” w odniesieniu jednak do malarstwa flamandzkiego podejmuje Pavlović w utworze Flamandski slikar (Malarz flamandzki) z tomiku Ulazak u Kremonu, który ze względu na zawężenie perspektywy do malarstwa holenderskiego nie został poddany szczegółowej interpretacji. 
i mora, treba shvatiti učenje

"o bogatstvu naroda", nasuprot obrtljivog

kapitala; - teoriju o višku vrednosti

koja se odliva u umetničke slike,

i ukazuju na ono što čovek sam upotrebljava:

apetit, želju.

A želja je predmeta

da se domognu istinskog čoveka

i da se iznad sveg ljudskog propnu.

Holenderska martwa natura

Posiłek bez jedzącego. Kawałek chleba

i ryba - są zawsze wieczerzą "ostatnią"; muszle

i szkło z jakiegoś nieznanego ołtarza

Poranek lśni w ostrzu i rękojeści noża

$\mathrm{z}$ agatu. Czerwone sukno jest fałdą

wielokrotnie krzepnącej krwi. Owoc obiera

niewidoczna ręka, po czym

odcina jego głowę i kładzie na półmisek.

Szklanki są uniesione jak żagle, płynące

ku światłu. Z chińskiej wazy

świątobliwy starzec spogląda na swoje śniadanie

spuściznę obrzędu ofiarnego i daru

A przezroczysty tulipan wznosi się wysoko

jak zboże wskrzeszone w polu.

Za dużo już chyba

o pochodzeniu grupowej architektury przedmiotów

zwanej martwą naturą.

Więcej w niej filozofii rzeczy

niż znaczeń i emblematów. Tu, wśród

drogocennych waz, pomarańczy,

winogron, nieposkromionej dziczy z lądu

i morza, należy zgłębiać wiedzę

„o bogactwie narodu”, przeciwieństwie kapitału

obrotowego; - teorię nadwyżki wartości 
przelanej w artystyczne obrazy

i wskazującej na to, czego używa sam człowiek:

apetyt, pragnienie.

A pragnieniem przedmiotów jest

dotarcie do prawdziwego człowieka

i wzniesienie się ponad to wszystko, co ludzkie.

Podobnie jak wcześniej analizowany, przywołany utwór Pavlovicia nie jest kontemplacją konkretnego dzieła malarskiego, ale samodzielną wypowiedzią poetycką, będącą refleksją na temat historii, istoty i funkcji martwej natury. Początkowa, opisowa część wiersza stanowi prezentację inwentarza artefaktów, składających się na kompozycję zwaną martwą naturą, literacką syntezę jej charakterystycznych elementów. Fakt, że oprócz chleba i ryb, będących w malarstwie holenderskim pochwałą codziennego życia w całej jego prostocie, znalazły się w niej przedmioty świadczące o przepychu, zamożności i zbytku: chińska porcelana, muszle, czerwona udrapowana materia, kielichy, cytryna, nóż o rękojeści z agatu oraz tulipan, może naprowadzać na obrazy Willema Kalfa (np. Stilleben mit chinesischer Porzellandose, 1662, olej na płótnie, Staatliche Museen, Berlin) i jego idiom malarski, jednak wydaje się, że celem Pavlovicia nie jest wskazanie stylu konkretnego twórcy, lecz fenomenologiczna prezentacja „istoty” jednego z gatunków malarstwa holenderskiego - martwej natury i jej cech specyficznych.

Enumeracyjnie zaprezentowany w wierszu serbskiego poety zestaw śniadaniowy nie jest jednak posiłkiem zwyczajnym. Przedstawione produkty spożywcze oraz naczynia stanowiące zastawę stołową zostają w wypowiedzi poetyckiej uosobione, żyją one niejako własnym, odrębnym życiem, wykraczając poza przypisaną im trywialną „śniadaniową” funkcjonalizację za sprawą symboliki przypisanych im znaczeń, które sytuują wskazane artefakty w sferze sacrum: chleb i ryby to aluzja do pierwszego rozmnożenia chleba, zboże (wskrzeszone) oraz kielich to symbole Eucharystii, krew stanowi nawiązanie do męki Pańskiej zaś odcięta głowa spoczywająca na półmisku jest aluzją do śmierci Jana Chrzciciela (wydarzenia, które nota bene rozegrało się podczas uczty wyprawionej przez Heroda Antypasa). Ich symboliczny wymiar zostaje wydobyty przez nazwanie „śniadania” mianem „ostatniej wieczerzy”, której gatunkowa doniosłość, dzięki odwołaniom do poprzedzającego śmierć Jezusa wydarzenia ustanawiającego Eucharystię, przenosi nas ze sfery gastronomicznej, zbytkowej i luksusowej (ale jednak) codzienności w obszar podniosłości i tajemnicy. Gdyby podążać tropem odniesień malarskich, można by pokusić się o stwierdzenie, że utwór Pavlovicia 
ma charakter palimpsestowy, dwuwarstwowy, spod powierzchni holenderskiej martwej natury jako głównego tematu utworu wyłania się przywołany aluzyjnie w warstwie symbolicznej motyw biblijny, którego najsłynniejszą malarską realizacją jest malowidło Leonarda da Vinci - Ostatnia wieczerza.

Jaki jest związek między odległym - jak mogłoby się wydawać - biblijnym motywem ostatniej wieczerzy a martwą naturą holenderską? W jakim celu Miodrag Pavlović konfrontuje ze sobą te dwa obrazy? Zestawiając przedstawienia ostatniej wieczerzy, której bohaterami są ludzie i przedmioty, z martwą naturą, której bohaterem są wyłącznie artefakty (człowiek - przedstawiony na chińskiej porcelanowej wazie „świątobliwy starzec”, który, jak żartobliwie stwierdza Pavlović, „spogląda na swoje śniadanie” - zostaje w opisanej przez niego martwej naturze uprzedmiotowiony, sprowadzony do wizerunku), poeta pokazuje proces wyabstrahowania grupy przedmiotów jako niezależnego i wiodącego tematu dzieła artystycznego, zmierzającego ku stopniowej laicyzacji martwej natury. Za pomocą myślowego skrótu, eliptycznie i aluzyjnie opowiada jej historię od czasów najwcześniejszych, czyli od jej pierwszych realizacji - odniesieniem do nich jest nazwanie martwej natury mianem „spuścizny obrzędu ofiarnego i daru", w którym zawarte jest nawiązanie do starożytnego xenionu: „daru gościnności” (10 (Sterling 1998: 22-23) - aż do wyodrębnienia przedmiotów, które zachowując swą symboliczną, emblematyczną funkcję, „uwolniły się” od obecności człowieka i uzyskały samodzielną godność oraz przyzwolenie na przedstawienie. Proces ten lapidarnie opisuje Tzvetan Todorov:

Tak oto od xvi wieku te nowe gatunki - portret, pejzaż, martwa natura, malarstwo rodzajowe - stopniowo utwierdzały swoje prawo bytu i zdobywały własną godność. [...] Przedmioty użytkowe, kwiaty, owoce przestały być dodatkami towarzyszącymi osobom i dały początek martwej naturze; zgodnie $\mathrm{z}$ formułą Malraux: „Holandia nie wymyśliła kładzenia ryby na półmisku, ale to, że przestała być ona posiłkiem apostołów" (Todorov 2012: 161).

Jednak wspomniane uwalnianie się od przypisanych przedmiotom znaczeń nie było całkowite, bowiem

Pojawiające się w twórczości Pavlovicia odwołania do czasów przedchrześcijańskich stanowią z jednej strony wyraz jego antropologicznych zainteresowań, z drugiej zaś rodzaj gestu światopoglądowego poety, występującego przeciwko wszelkim formom religijnego, społecznego i politycznego dogmatyzmu. Nie bez znaczenia jest fakt obecności w wierszach serbskiego twórcy figury heretyka, w którego postawie przejawia się „humanistyczna etyka człowieka zbuntowanego” (Đorđević 1984: 106). 
[...] w XVI i w pierwszej połowie XVII wieku dla malarzy i odbiorców ich dzieł, przedstawiana w martwych naturach rzeczywistość była symbolicznym obrazem wartości i pojęć abstrakcyjnych. Poprzez oddziaływanie na zmysły obraz miał odwoływać się do intelektu widza i skłaniać go nad sensem ludzkiej egzystencji, nad zagadnieniami etyki i wiary. Przekonanie o dydaktycznej mocy sztuki było powszechne (Małachowicz 1993: bez paginacji).

Część opisową podmiot liryczny podsumowuje (przerywając wywód, jakby nagle zorientował się, że tematowi temu poświęca zbyt wiele czasu) autorefleksyjnym, samodyscyplinującym komentarzem na temat swojej wypowiedzi i jej tematyki. „Za dużo już chyba - stwierdza - o pochodzeniu grupowej architektury przedmiotów zwanej martwą naturą". Określając martwą naturę mianem "grupowej architektury przedmiotów”, wskazującym na fakt poddania ich kontroli intelektualnej, która przejawia się zarówno w nadawaniu symbolicznych znaczeń przedmiotom, jak i w ich uporządkowaniu na płótnie, podmiot liryczny polemicznie komentuje nazwę gatunkową sugerującą związki sztuki z naturą.

Przypisanie martwej naturze miana architektury jest niespodziewanym zwrotem w tym utworze. Jej zaprezentowana wcześniej definicja przywołuje bowiem spiritus movens tego gatunku, jego wytwórcę i adresata - człowieka. Zauważmy, że opis artefaktów zostaje w utworze poetyckim uzupełniony informacją o nieuobecnionym w obrazie malarskim sprawcy tej kompozycji - wywód o przedmiotach dopełnia informacja o skutkach działania kogoś, czyja postać, wizerunek, pozostaje niewidoczna na obrazie: „Posiłek bez jedzącego”, „Owoc obiera / niewidoczna ręka, po czym / odcina jego głowę i kładzie na talerz”. W tym krótkim fragmencie uwidacznia się nie tylko potrzeba przywołania człowieka jako sprawcy martwej natury, sprawcy, dla którego zobrazowane malarsko chleb i wino są posiłkiem. Martwa natura - uwolnione od człowieka (w sensie jego przedstawienia) przedmioty - punkt dojścia swoistej linii emancypacyjnej tematu malarskiego, jest pretekstem do artystycznej prezentacji problematyki relacji człowieka i przedmiotów. W swoim odczytaniu holenderskiej martwej natury Pavlović dokonuje zatem operacji przeciwstawnej do przemian, które doprowadziły do ukonstytuowania się tego gatunku - przywraca obecność człowieka na wizerunku bez konieczności jego przedstawiania, wskazuje zatem, podobnie jak Barthes w swoim eseju, na współistnienie rzeczy i człowieka jako istotę holenderskich martwych natur.

Z kolei dalsza część wypowiedzi poetyckiej, będąca prezentacją ontologii martwej natury: „Więcej w niej filozofii rzeczy / niż znaczeń i emblematów”, stanowi konfrontację perspektywy historycznej i współczesnej. Wyłania się 
z niej głos „ja” lirycznego, który prezentując różne style odbioru, jawi się jako medium pomiędzy nimi.

Pochwała codzienności wyrażona za pomocą obrazów dorodnych, okazałych przedmiotów i kunsztownych naczyń, apoteoza zbytku jest u Pavlovicia uwolniona od dekadencji - świadomości, że dojrzałość niesie za sobą piętno przemijania, krótkotrwałości, schyłku, śmierci. Nie jest to styl holenderskich martwych natur, w których zderzenie sfery ducha i materii oddające dwoistą naturę świata miało w sposób symboliczny obrazować

[...] rozterkę człowieka postawionego wobec wyboru między pokusami doczesności, dążeniem do bogactwa i zaszczytów ziemskich a wstrzemięźliwością i pobożną refleksją, w której zawiera się świadomość przemijania wszelkiej materii i nieuchronności śmierci (Małachowicz 1993: bez paginacji).

Przywołanie wartości wyższych, które stoi u podłoża holenderskiej martwej natury, odbywa się u Pavlovicia nie poprzez odesłanie do symboliki wanitatywnej, lecz afirmację przedmiotów, które uczestnicząc w rytuałach codzienności, potwierdzają nieustannie swoje związki z sacrum (pogańskim i chrześcijańskim) oraz mitem. Pavlović finezyjnie wydobywa także pochwałę dostatku i dobrobytu, przywiązanie do doczesności, do „rzeczy świata tego”, które - jak zauważa Remo Bodei - „[...] dla pracowitych kalwinów nie jest grzechem, lecz ukazuje pośrednio boską przychylność" (Bodei 2016: 137). Poeta stawia pytanie o sens bogactwa kojarzonego ze splendorem i przepychem, wartościami materialnymi, towarami i ich obiegiem. Generowany przez nie nadmiar (czy nadwyżka, jak stwierdza poeta, przywołując tytuł opublikowanego w 1776 roku pionierskiego dzieła z zakresu ekonomii szkockiego myśliciela Adama Smitha Badania nad natura i przyczynami bogactwa narodów, w którym termin „bogactwo” jest utożsamiony z ludzką pracą) zostaje przelany w dzieło sztuki, artystyczną wizję zaświadczającą o człowieku, o jego instynktach, biologicznych potrzebach i zmysłowości.

Afirmacja przedmiotów u Pavlovicia nie polega zatem na ich realistycznym, wiernym, mimetycznym odtworzeniu, wyabstrahowaniu i usamodzielnieniu od człowieka, ale - paradoksalnie - na wskazaniu na ich relację z tym, który na płótnie nie został przedstawiony. Wydobywając kwestie związane z problematyką reprezentacji i uobecniania, Pavlović stwierdza, że człowiek niejako wpisany jest w ten obraz. Dlatego zapewne bardziej niż technika malarska, zmysłowy charakter martwej natury oraz sposób prezentacji rzeczy w dziele sztuki i ich transpozycji na obraz malarski czy będący wyrazem architektoniki intelektualnej wymiar emblematyczny, symboliczny, poetę interesuje natura przedmiotów, 
głębia ich bycia, sposób istnienia w relacji z człowiekiem, czyli - jak stwierdza sam Pavlović - „filozofia rzeczy”. Poeta prezentuje je jako towary (w ich aspekcie ekonomicznym), użyteczne narzędzia (aspekcie technicznym) czy przedmioty konsumpcji (w aspekcie materialno-zmysłowym), ale zarazem wskazuje na ich wynoszenie się ponad to, co ludzkie. W „powrocie do rzeczy” Pavlovicia ujawnia się chęć przezwyciężenia ich traktowania jako wyłącznie wytworów materialnych, zaświadczających status ekonomiczny, uczestniczących w wymianie dóbr materialnych. Za pomocą paradoksu - zrównując elementy przynależące do świata natury z artefaktami - poeta dokonuje problematyzacji opozycji ludzkie nieludzkie, a tym samym kwestionuje opozycję natura - kultura.

Wskazując na demiurgiczną istotę człowieka jako wytwórcy i odbiorcy obiektu sztuki, Pavlović wydobywa paradoks, który polega na tym, że produkty spożywcze i luksusowe przedmioty, zaświadczające o zmysłowości człowieka i jego potrzebach biologicznych, umożliwiają mu wzbicie się ponad materię. Jednak choć działalność artystyczna pozwala człowiekowi wykraczać poza świat natury, którego jest nieodłącznym elementem, nie świadczy ona - zdaniem serbskiego poety - o uprzywilejowanej pozycji w świecie, świat i człowiek od zarania swoich dziejów stanowią bowiem jedność.

Egzemplifikacją tej problematyki jest kolejny utwór, prezentujący przedstawienie malarskie wnętrza mieszczańskiego domu:

\section{Emanuel de Vite: Devojka za virginalom}

Da li je pre ili posle podne zateklo

devojku nadnetu iznad virginala?

Osvetljeni pločnici izgledaju kao note.

Slika je podeljena na tri sobe

slično muzici u tri stava. Slikar je

predsatvljao ono što se svira.

Ili je sviračica preuzela u ruke

Što je slika htela da dočara.

Note su svetlost i senka,

Predmet je svaki čista akustika:

Staklo, ploča ormara, zavesni

Somot i prozor...on sam je čudo,

Njegova svetlost nadmašuje mudrost

veka. Što je ta mudrost prešla u svirku, 
o tome je doneo odluku prostor.

Neopoziv. Njegovi talasi odbijaju se

o tapete; tvrdina stvarnosti

stekla je samu sebe. I više se ne otvara.

Emanuel de Witte: Grająca na wirginale

Przed- czy popołudnie

Zastało dziewczynę pochyloną nad wirginałem?

Oświetlone kafle wyglądają jak nuty

Obraz został podzielony na trzy pokoje

jak utwór muzyczny na trzy części. Malarz

Przedstawiał to, co słychać.

Albo grająca wzięła w ręce

To, co chciał wyczarować obraz.

Nuty są światłem i cieniem.

Każdy z przedmiotów czystą akustyką:

Szyby, płyta szafy, aksamit

Zasłon i okno... ono samo jest cudem,

Jego światło przewyższa mądrość

dziejów. O przemianie tej mądrości w muzykę

zadecydowała przestrzeń.

Nieprzejednana. Jego fale odbijają się

Od tapet; nieustępliwość rzeczywistości

Osiągnęła samą siebie. I już się nie otwiera.

Tematem ekfrazy Pavlovicia nie jest historia, którą podglądamy na obrazie Emanuela de Vitte (Wnętrze z kobietą grającą na wirginale, ok. 166o-1665, olej na płótnie, Montreal Museum of Fine Arts; kopia tego obrazu datowana na lata 1665-1670, również autorstwa de Witte, znajduje się w Museum Boijmans Van Beuningen, Rotterdam). Ukazana na płótnie intymna scena przedstawiająca leżącego w okotarowanym łożu z baldachimem mężczyznę, który przysłuchuje się grze tytułowej bohaterki utworu, zostaje w wierszu Pavlovicia całkowicie pominięta. Poety nie interesuje niedopowiedzenie relacji między widniejącymi na obrazie osobami, czyli narracyjny (trywialny) aspekt dzieła malarskiego. Autor wiersza nie opisuje tego, o czym wymownie milczy dzieło holenderskiego 
mistrza, intrygując widza, lecz przeciwnie - kieruje on swoją uwagę ku temu, co zostaje przez malarza wyrażone za pomocą światła, koloru i kompozycji, a zatem ku warsztatowi i technice twórców malarstwa holenderskiego XvII wieku. Pavlović czyni tematem swojego obrazu światło, które staje się znakiem objawiania się harmonii (mądrości), przez okno przenikającej do przedstawionego wnętrza i wypełniającej je. Światło jest źródłem wydarzania się tego, co obecne, ale niewyrażalne, co konstytuuje się na styku różnorodnych wrażeń zmysłowych, jest wizualnym przejawem przenikania do rzeczywistości empirycznej harmonii objawiającej mądrość (logos), której istotę stanowi korespondencja różnych sfer rzeczywistości. Można zatem stwierdzić, że poeta interpretuje obraz malarski jako tekst muzyczny, wyrażając w ten sposób przekonanie o harmonijnej naturze świata, czyli wpisując w dzieło malarskie opartą na matematycznych zasadach Pitagorejską teorię piękna, której podstawą stała się obserwacja akustyczna (James 1996: 41-43). „Nuty są światłem i cieniem. Każdy z przedmiotów czystą akustyką" - stwierdza podmiot liryczny. Harmonia, którą za pomocą malarskich środków przedstawia płótno, w interpretacji poety jest odbiciem ładu panującego we Wszechświecie, muzycznej natury świata - muzyki sfer. To synestezyjne przenikanie obrazu (barw i przestrzeni) oraz dźwięków dopełnia fakt, że także czytany przez nas wiersz stanowi opis tego, czego nie możemy usłyszeć, a co zostało przedstawione za pomocą środków malarskich.

Fakt, że architektoniczne wnętrze zostaje przez serbskiego poetę porównane do (trójdzielnej) kompozycji muzycznej, nie jest jedynie nawiązaniem do przekonania pitagorejczyków na temat struktury kosmosu. Wydaje się, że zawoalowaną aluzją do tej tezy, która była „wielkim tematem myśli greckiej”, a która - co nie bez znaczenia - „stała się w epoce Humanizmu wspólnym mianownikiem dla teorii muzyki, architektury, rzeźby i malarstwa" (Mossakowski 1980: 51), jest rozpoczynające utwór pytanie o porę dnia. Stanowi ono nawiązanie do Popołudnia fauna, poematu Stephane’a Mallarmégo, skonstruowanego właśnie na podobieństwo trójdzielnego koncertu (nota bene, odnotować należy, żartobliwie problem ujmując, pewne niedopatrzenie poety - na obrazie nie przedstawiono wnętrza trzypokojowego, lecz - co stwierdzić można przy wnikliwym oglądzie - są na nim ukazane cztery pomieszczenia, podobnie jak nie ma na nim szafy, chyba że uznać za nią pudło wirginału).

Podnosząc kwestię, co było uprzednie - widok, który zainspirował grającą do jego przełożenia na język muzyki, czy muzyka będąca natchnieniem malarza, podmiot liryczny nie tylko sugeruje wzajemną korespondencję, współbrzmienie i przenikanie doznań, wyraża przekonanie o synestezyjnej naturze świata, ale także pyta o miejsce człowieka i jego udział w tej tajemnicy. Wydaje się, że jako twórca uczestniczy on w harmonii wszechświata, odtwarzając matematyczne 
proporcje, zbliża się do niebiańskiego porządku, a zatem - jeżeli odczytać idee pitagorejczyków w duchu renesansowego neoplatonizmu (Mossakowski 1980: 52-54) - jego kreatywna działalność jest ponowieniem boskiego aktu tworzenia kosmicznego (boskiego) ładu, harmonii.

Wypowiedź podmiotu nie jest wyrazem jego przekonań, lecz „głosem” holenderskiego artysty. Pytając o intencję malarza, poeta rekonstruuje zamiar twórcy malarskiego przedstawienia - przywołuje niejako ducha epoki, z której wywodzi się płótno - przypomnijmy, że teoria Pitagorasa, zaadaptowana przez Boecjusza w średniowieczu, odżyła w wielu teoriach spekulatywnych XVI, XVII i XVIII wieku" ${ }^{11}$. Sygnaturę autorską wiersza, współczesną perspektywę odczytania malarskiego dzieła obnaża zaskakujący komentarz, który wieńczy utwór. Podmiot liryczny rewiduje w nim przekonanie o wyższości ducha nad materią, zwracając uwagę na fakt, że to właśnie materia jest katalizatorem objawiania harmonii i doskonałości. Bez zamkniętej, ograniczonej i „nieprzejednanej”, jak pisze poeta, przestrzeni wnętrza uobecnienie niewyrażalnego nie byłoby możliwe. Ta polemika z przekonaniami holenderskiego malarza staje się zarazem antyobrazem - rewersem jego przekonań.

Przenikanie się sfery sacrum i profanum, materii i ducha, natury i kultury nawiązuje do pitagorejskiej idei łączenia przeciwieństw jako naczelnej zasady harmonii, na której opiera się istnienie całego kosmosu. Poszukiwania źródła ładu poza obszarem ludzkiego ego wynikają z faktu, że w antropologii Pavlovicia człowiek jest nieodłącznym elementem wszechświata, w którym zyskuje jednocześnie status demiurga powołującego do istnienia nowe byty i rozumnego, lecz niedoskonałego zwierzęcia, zaś jego kulturotwórcza (mitotwórcza) działalność stanowi rodzaj kompensacji owego braku w celu oswojenia rzeczywistości (Blumenberg 2009: 5-7). Sztuka nie jest dla Pavlovicia (jedynie) odwzorowaniem i medium bytu natury, jak twierdzili romantycy, jest raczej, także za sprawą autoreferencjalności, narzędziem samopoznania.

Poety nie interesuje czysty wymiar dzieła, działalność artystyczna jest zanurzona w perspektywie humanistycznej, bez człowieka nie jest ona możliwa. Dla serbskiego poety aktywność ta nie jest wyłącznie źródłem przeżycia estetycznego, ale raczej korelatem refleksji (eseistycznej), której przedmiotem jest człowiek i jego miejsce w otaczającym świecie. Jak bowiem stwierdza Pavlović, „wyrażanie intensywności emocjonalnych w dziedzinie sztuki, jaką jest poezja, [...] wymaga o wiele bardziej zapośredniczonej strategii artystycz-

11 Historię idei „muzyki sfer” do współczesności omawia szczegółowo Jamie James (James 1996), tematykę tę referuje także w swojej książce Magdalena Wasilewska-Chmura (Wasilewska-Chmura 2011). 
nej”, konkretyzację emocji osiąga się zaś za pomocą metafory, obrazu poetyckiego, który jest „pewną czynnością myślową, intelektualną i emocjonalnym zagęszczeniem” (Pavlović 1958: 51-53). Źródeł typu namysłu, odcinającego się od romantycznej wizji autorstwa, wykraczającego poza własne, indywidualne doświadczenie oraz przeżywanie w celu uwolnienia dzieła od obciążeń psychologizmu i biografizmu należy upatrywać w znaczeniu, jakie serbski poeta przydawał Eliotowskiej koncepcji bezosobowości wyłożonej w eseju Tradycja i talent indywidualny: „Poezja to nie dawanie upustu wzruszeniom, ale ucieczka od wzruszenia, to nie wyrażanie osobowości, lecz ucieczka od osobowości. Ale oczywiście jedynie ci, którzy posiadają osobowość i doświadczają wzruszeń, rozumieją, co to znaczy pragnąć dystansu od nich” (Eliot 1998b: 32). Drogą do osiągnięcia tego celu było sprowadzenie emocji do korelatu przedmiotowego, które angloamerykański poeta wyjaśniał następująco:

Wyrazić uczucie w formie artystycznej można, tylko znajdując korelat obiektywny, a więc zestaw przedmiotów, jakąś sytuację, jakiś ciąg wydarzeń, które powinny stać się formułą tego właśnie konkretnego uczuciowego stanu, skutkiem czego przywołanie faktów o charakterze zewnętrznym, które wyczerpać się muszą w doznaniu zmysłowym, przywoła również odpowiedni stan uczuciowy (Eliot 1998a: 118).

Utwory Pavlovicia są wypowiedziami poetyckimi, uwolnionymi od impresyjności, przeżycia, emocji, bezosobowym głosem podmiotu lirycznego, unikającego personalizacji i możliwości rozpoznania. Jednak uniknięcie tego w Eliotowski sposób rozumianego subiektywizmu nie jest możliwe. Jak bowiem zauważa Dziadek:

Często dzieje się tak, że poeci wybierają z obrazu to, co mamy zobaczyć, to, co oni sami chcą nam pokazać. Obraz i zawarte w nim znaki stymulują wyobraźnię i pozwalają pisarzowi rozwinąć subiektywną interpretację. Ów aspekt subiektywny jest w przypadku ekfrazy szczególnie istotny. Ekfraza opisuje dzieło sztuki, ale nie tylko, opisuje bowiem także tego, kto to dzieło ogląda. Opis zostaje w pewien sposób podyktowany przez interpretację dokonaną przez widza-autora. Ekfrazy, zwłaszcza w poezji współczesnej, nie da się sprowadzić do czystego mimetyzmu czy do samej tylko kwestii opisu. Rzecz w tym, że obraz w danym tekście literackim ma zwykle charakter pretekstowy, staje się punktem wyjścia powstania autonomicznego dzieła literackiego; dzieła sztuki w utworach literackich często traktowane są jako teksty 
do przeczytania, teksty poddawane lekturze i interpretacji z wyraźnie zaznaczoną sygnaturą autorską, na którą składają się zarówno recepcja subiektywna, jak i charakterystyczne, niepowtarzalne w przypadku każdego poety cechy języka (Dziadek 2004: 71-73).

Dlatego kategoria ekspresyjności to dla Pavlovicia nie kwestia uczucia, ale raczej zmysłowego postrzegania wrażeń, kwestia operowania światłem i kompozycji. Przetwarzając dzieło malarskie na język poezji, Pavlović opisuje nie swoje emocje, ale intelektualną refleksję na temat tego, co nie zostaje przedstawione na obrazie, choć zostaje w nim uobecnione. Dominującym zaś problemem, który wydobywa Pavlović, są kwestie relacji dzieła i twórcy oraz sposobu przedstawiania, a także namysł nad uwarunkowanym historycznie stylem odbioru. Wnikając w związane ze sztuką kwestie historyczne, traktuje je jako miejsca wspólne doświadczeń różnorodnych kręgów kulturowych. W swoich przekładach malarstwa na język poezji Pavlović, posługując się „antyobrazem”, staje się więc raczej interpretatorem tekstu sztuki, wchodzącym w polemikę z utrwalonymi wyobrażeniami i przekonaniami, aniżeli reporterem czy „impresjonistą” (Kudyba 2008: 147-154).

\section{| Bibliografia}

Barthes Roland (1964), Le Monde-Object, w: tenże, Essais crtitiques, Seuil, Paris, s. 19-28, https://tinyurl.com/58zwup5m [dostęp: 18.03.2021].

Białostocki Jan (1989), Portrety kościołów Pietera Saenredama: sacrum czy profanum?, w: Sacrum i sztuka, red. Nawojka Cieślińska, Wydawnictwo Znak, Kraków, s. 39-43.

Biegański Piotr (1974), Architektura. Sztuka kształtowania przestrzeni, Wydawnictwa Artystyczne i Filmowe, Warszawa.

Bieńkowski Zbigniew (1993), W ojczyźnie przedmiotu, w: tenże, Ćwierć wieku intymności. Szkice o poezji i nie poezji, Oficyna Wydawnicza „Agawa”, Warszawa, s. 62-70.

Blumenberg Hans (2009), Praca nad mitem, przeł. Kamilla Najdek, Michał Herer, Zbigniew Zwoliński, Oficyna Naukowa, Warszawa.

Bodei Remo (2016), O życiu rzeczy, przeł. Alicja Bielak, przekład przejrzeli i poprawili Mateusz Śliwa i Katarzyna Skórska, Przypis, Łódź.

Brajović Tihomir (2010), Miodrag Pavlović i moderna pesnička samosvest, w: Pesništvo i književna misao Miodraga Pavlovića, red. Jovan Delić, Institut za književnost i umetnost, Učiteljski fakultet, Beograd, s. 111-132. 
Caygill Howard (2002), Barthes and the Lesson of Saenredam, „Diacritics”, nr 1, s. $38-48$.

Dąbrowska-Partyka Maria (2003a), Świadectwa i mistyfikacje, w: taż, Świadectwa i mistyfikacje. Przed i po Jugosławii, Wydawnictwo Uniwersytetu Jagiellońskiego, Kraków, s. 203-217.

Dąbrowska-Partyka Maria (2003b), „...wbrew wszystkim danym o mnie...”, w: taż, Świadectwa i mistyfikacje. Przed i po Jugosławii, Wydawnictwo Uniwersytetu Jagiellońskiego, Kraków, s. 251-279.

Dąbrowska-Partyka Maria (2004), Pismo jako znak tożsamości, w: taż, Literatura pogranicza. Pogranicza literatury, Wydawnictwo Uniwersytetu Jagiellońskiego, Kraków, s. 133-145.

Delić Jovan (2010), Uz poetiku Miodraga Pavlovića, w: Pesništvo i književna misao Miodraga Pavlovića, red. Jovan Delić, Institut za književnost i umetnost, Učiteljski fakultet, Beograd, s. 47-6o.

Despić Đorđe (2008), Poreklo pesme. Potencijal intertekstualnosti u poezji Miodraga Pavlovića, Agora, Zrenjanin.

Đorđević Časlav (1984), Miodrag Pavlović pesnik humanističke etike, Svetlost, Kragujevac.

Đorđević Časlav (1997), Pesnikovo svevideće oko, Prosveta, Beograd.

Dziadek Adam (2004), Obrazy i wiersze, Wydawnictwo Uniwersytetu Śląskiego, Katowice.

Eliot Thomas Stearns (1998a), Hamlet, przeł. Helena Pręczkowska, w: tenże, Kto to jest klasyk i inne eseje, przeł. Magdalena Heydel i in., Wydawnictwo Znak, Kraków, s. 114-120.

Eliot Thomas Stearns (1998b), Tradycja i talent indywidualny, przeł. Helena Pręczkowska, w: tenże, Kto to jest klasyk i inne eseje, przeł. Magdalena Heydel i in., Wydawnictwo Znak, Kraków, s. 24-33.

Gadamer Hans-Georg (1993), Aktualność piękna. Sztuka jako gra, symbol i święto, przeł. Krystyna Krzemieniowa, Oficyna Naukowa, Warszawa.

James Jamie (1996), Muzyka sfer. O muzyce, nauce i naturalnym porzadku wszechświata, przeł. Mieczysław Godyń, Znak, Kraków.

Kluba Agnieszka (2016), Herbert - ikonofil? Rekonstrukcja eseisty, w: Ikonoklazm i ikonofilia. Między historią a wspótczesnością, red. Agata Stankowska, Maciej Telicki, Wydawnictwo Poznańskiego Towarzystwa Przyjaciół Nauk, Poznań, s. $105-140$.

Kocić Zlata (1996), Rtanjska svetila, Prosveta, Niš.

Kordić Radoman (1976), Govor s dna, Vuk Karadžić, Beograd.

Kornhauser Julian (1980), Współczesna poezja jugosłowiańska (1941-1970), Zakład Narodowy imienia Ossolińskich, Wrocław-Warszawa-KrakówGdańsk. 
Kudyba Wojciech (2008), Trzy żywioły ekfrazy - impresja, hermeneutyka, reportaż, w: Interakcje sztuk: literatura, malarstwo, ekfraza, red. Dorota Heck, Wydawnictwo GAJT, Wrocław, s. 147-154.

Małachowicz Hanna (1993), Martwe natury mistrzów niderlandzkich, Arx Regia Ośrodek Wydawniczy Zamku Królewskiego w Warszawie, Warszawa.

Markowski Michał Paweł (1999), Pragnienie obecności. Filozofie reprezentacji od Platona do Kartezjusza, słowo/obraz terytoria, Gdańsk.

Mossakowski Stanisław (1980), Pitagorejska teoria piękna i jej rola $w$ teoriach artystycznych i naukowych doby Humanizmu, w: tenże, Sztuka jako świadectwo czasu. Studia z pogranicza historii sztuki i historii idei, Wydawnictwo Arkady, Warszawa, s. 43-55.

Palavestra Predrag (2008), Istorija srpske književne kritike 1768-2007, t. 2, Matica srpska, Novi Sad.

Pavlović Miodrag (1958), Rokovi poezije, Srpska književna zadruga, Beograd.

Pavlović Miodrag (1979), Mit i poezja, przeł. Joanna Salamon, Wydawnictwo Literackie, Kraków.

Pavlović Miodrag (1981), Izabrana dela, t. 4: Poetika modernog, Vuk Karadžić, Beograd, s. 202-262.

Pavlović Miodrag (1989), Ulazak u Kremonu. Pesme, Nolit, Beograd.

Pavlović Miodrag (2018a), Modernost i pesništvo, w: Miodrag Pavlović, red. Đorđe Despić, Izdavački centar Novog Sada, Novi Sad, s. 263-265.

Pavlović Miodrag (2018b), Pesnička imaginacija kao neposredno iskustvo, w: Miodrag Pavlović, red. Đorđe Despić, Izdavački centar Novog Sada, Novi Sad, s. $265-271$.

Popović Bogdan A. (1985), Epski rasponi Miodraga Pavlovića, Grafos, Beograd.

Sterling Charles (1998), Martwa natura. Od starożytności po wiek xx, przeł. Joanna Pollakówna, Wiktor Dłuski, Wydawnictwa Artystyczne i Filmowe, Wydawnictwa Naukowe Pwn, Warszawa.

Stojanović-Pantović Bojana (2010), Poetičke i semantičke specifičnosti zbirke Ulazak u Kremonu Miodraga Pavlovića, w: Pesništvo i književna misao Miodraga Pavlovića, red. Jovan Delić, Institut za književnost i umetnost, Učiteljski fakultet, Beograd, s. 433-448.

Śniedziewska Magdalena (2014), Siedemnastowieczne malarstwo holenderskie w literaturze polskiej po 1918 roku, Wydawnictwo Naukowe Uniwersytetu Mikołaja Kopernika, Torun.

Todorov Tzvetan (2012), Gatunek codzienności, przeł. Magdalena Śniedziewska, „Poznańskie Studia Polonistyczne. Seria Literacka”, nr 19, s. 159-170.

Wasilewska-Chmura Magdalena (2011), Przestrzeń intermedialna literatury i muzyki. Muzyka jako model i tworzywo w szwedzkiej poezji późnego modernizmu i neoawangardy, Wydawnictwo Uniwersytetu Jagiellońskiego, Kraków. 


\section{| Abstrakt \\ Sylwia NowaK-BajCar \\ Opisać nieprzedstawione. Malarstwo holenderskie w antyobrazach Miodraga Pavlovicia}

W twórczości zmarłego w 2014 roku poety serbskiego Miodraga Pavlovicia refleksja nad sztuką wiąże się z zagadnieniem związków przeszłości i współczesności oraz rolą, jaką odgrywa w niej wschodnia i zachodnia tradycja kulturowa jako element budowy tożsamości (losów) Bałkanów. Wkraczając w obszar niemal całkowicie pomijany przez interpretatorów dzieł wybitnego twórcy, Miodraga Pavlovicia, określanego przez krytyków mianem „eliotowskiej figury” literatury serbskiej, przedstawiam przyczyny jego zainteresowania pracami siedemnastowiecznego malarstwa holenderskiego, wyjaśniam strategie ich przekładów na język poezji oraz omawiam zagadnienie obecności (śladów) człowieka w dziele sztuki. Kluczem interpretacyjnym tego badawczego przedsięwzięcia jest wykorzystywane przez serbskiego poetę pojęcie antyobrazu, będące wyrazem wymierzonej w dogmatyzm estetyki oporu opartej na przekonaniu, że sztuka stanowi narzędzie umożliwiające człowiekowi samopoznanie.

Słowa kluczowe: Miodrag Pavlović; antyobraz; hypotypoza; ekfraza; malarstwo holenderskie Xvı wieku; człowiek w świecie rzeczy; uobecnianie

\section{| Abstract}

\section{SylWia NowAK-BAJCAR}

\section{Describe not Shown. Dutch Painting in Anti-images of Miodrag Pavlović}

In the works of the Serbian poet Miodrag Pavlović, who died in 2014, reflection on art is related to the issue of the relationship between the past and the present and the role played in it by the eastern and western cultural tradition as an element of building the identity (fate) of the Balkans. Entering the area almost completely ignored by the interpreters of the works of this eminent author, described by critics as the "Eliot figure" of Serbian literature, I present the reasons for his interest in the works of 17th-century Dutch painting, explain the strategies of their translations into the language of poetry and discuss the issue of human presence (traces) in a work of art i.e. his humanistic dimension. For this purpose, I refer to the concept 
of anti-image used by the Serbian poet, which is an expression of anti-dogmatism and the belief that art enables man to self-knowledge.

Keywords: Miodrag Pavlović; anti-image; hypotyposis; ekphrasis; 17th-century Dutch painting; man in the world of objects; making present

\section{| Nota o autorze}

Sylwia Nowak-Bajcar - prof. uJ, dr hab., absolwentka serbistyki i kroatystyki w Instytucie Filologii Słowiańskiej Uniwersytetu Jagiellońskiego, gdzie pracuje od 1995 roku. Jej zainteresowania naukowe skupiają się wokół śladów historii w literaturze i kulturze (szczególnie w literaturach postjugosłowiańskich xx i XxI wieku). Jest autorką artykułów o tematyce literaturoznawczej i kulturoznawczej, tekstów krytycznoliterackich, przekładów oraz książek: Monolog jako światopogląd. Proza Slobodana Selenicia (2001), Mapy czasu. Serbska proza postmodernistyczna wobec wyzwań epoki (2010), Helena, kobieta, której nie ma i która jest. Krakowska biografia Ivo Andricia (2013).

E-mail: s.nowak-bajcar@uj.edu.pl

ORCID: 0000-0002-1537-6268 
